\title{
Treatment of chromium(VI) solutions in a pilot-scale bioreactor through a biofilm of Arthrobacter viscosus supported on GAC
}

\author{
C. Quintelas *, B. Fonseca, B. Silva, H. Figueiredo, T. Tavares \\ IBB-Institute for Biotechnology and Bioengineering, Centre of Biological Engineering, University of Minho, Campus de Gualtar, 4710-057 Braga, Portugal
}

\section{A R T I C L E I N F O}

\section{Article history:}

Received 28 February 2008

Received in revised form 5 May 2008

Accepted 6 May 2008

Available online 18 June 2008

\section{Keywords:}

Biofilm

Bioreactor

Chromium

Isotherms

Modelling

\begin{abstract}
A B S T R A C T
The aim of this work is to evaluate the applicability of a biofilm to the removal of chromium in solution, at a pilot scale. The effect of the initial concentration of metal on the biosorption behavior of an Arthrobacter viscosus biofilm supported on granular activated carbon, in batch and column essays was also analyzed. Six isotherm equations have been tested in the present study. The best fit was obtained with the Freundlich model. It was observed that as the initial chromium concentration increases, the uptake increases too, but the removal percentage decreases, with values between $95.20 \%\left(C_{0}=5 \mathrm{mg} / \mathrm{l}\right)$ and $38.28 \%\left(C_{0}=1000 \mathrm{mg} / \mathrm{l}\right)$. The batch adsorption studies were used to develop a pilot bioreactor able to remove chromium from aqueous solutions. Data obtained in a pilot-scale reactor showed an average removal percentage of $99.9 \%$, during the first 30 days, for the initial concentration of $10 \mathrm{mg} / \mathrm{l}$ and an average removal percentage of $72 \%$, for the same period and for the initial concentration of $100 \mathrm{mg} / \mathrm{l}$. Uptake values of $11.35 \mathrm{mg} / \mathrm{g}$ and $14.55 \mathrm{mg} / \mathrm{g}$ were obtained, respectively, for the initial concentration of 10 and $100 \mathrm{mg} / \mathrm{l}$. The results obtained are very promising and encourage the utilization of this biofilm in environmental applications.
\end{abstract}

(c) 2008 Elsevier Ltd. All rights reserved.

\section{Introduction}

The pollution caused by heavy metals in wastewater has always been a very serious problem because these elements are not biodegradable and can accumulate in living tissues (Deng et al., 2006). Chromium is widely used in various important industrial applications including steel production, electro-plating, leather tanning, nuclear power production, textile industries, wood preservation, anodising of aluminium, water-cooling and chromate preparation (Garg et al., 2007). The hexavalent form of chromium, usually present in the form of chromate $\left(\mathrm{CrO}_{4}^{2-}\right)$ and dichromate $\left(\mathrm{Cr}_{2} \mathrm{O}_{7}^{2-}\right)$, possesses significant higher levels of toxicity than other valence states (Horsfall et al., 2006).

The conventional methods for heavy metal removal from industrial effluents are precipitation, coagulation, ion exchange, cementation, electro-dialysis, electro-winning, electro-coagulation and reverse osmosis (Ahluwalia and Goyal, 2007). These technologies are often inefficient and/or expensive, mainly when applied to dilute solutions, usually generating huge volumes of sludge containing high levels of heavy metals, which have to be disposed. Due to these limitations, new technologies are necessary (Cossich et al., 2004). Biosorption of heavy metals by microbial cells has been recognized as a potential alternative to the traditional treatment technologies for waste streams and natural waters (Özer et al., 2004).

\footnotetext{
* Corresponding author. Tel.: +351 253604400; fax: +351253678986.

E-mail address: cquintelas@deb.uminho.pt (C. Quintelas).
}

Many microorganisms are known to be able to concentrate metal species from dilute aqueous solutions and to accumulate them within their cell structure. These microorganisms include yeasts (Han et al., 2006; Goyal et al., 2003; Solóniz et al., 2002; Muter et al., 2002), fungi (Bayramoglu et al., 2006; Akar and Tunali, 2006; Tunali et al., 2005; Arica et al., 2004), algae (Aksu and Donmez, 2006; Kiran et al., 2007; Arica et al., 2005; Hashim and Chu, 2004) and bacteria (Tunali et al., 2006; Kazy et al., 2006; Quintelas et al., 2006, 2008a, b; Lameiras et al., 2008).

The applicability of bacteria as biosorbents has some advantages due to their small size, their ubiquity, their ability to grow under controlled conditions and their resilience to a wide range of environmental situations (Urrutia, 1997). On the other hand, activated carbons are potential adsorbents for the removal of heavy metals from industrial wastewater, due to their high surface area, microporous character and chemical nature of their surface, their high adsorption capacity and fast adsorption kinetics (Kobya et al., 2005; Song et al., 2006). Previous studies developed by Satapathy et al. (2005) show that the maximum removal obtained for chromium using GAC was 60-65\% (batch essays). The use of a biosorption system consisting of a biofilm supported on granular activated carbon allows to combine and even to enhance the ability of both, bacteria and activated carbon, to remove chromium and consequently increase the maximum removal.

Arthrobacter species is of particular interest because of its high potential for bioremediation. Bacteria can detoxify chromium wastewater, by either reduction or accumulation inside the cells 
and/or adsorption of the ion on their surface (Asatiani et al., 2004). These authors also affirm that once inside a cell, $\mathrm{Cr}(\mathrm{VI})$ can be reduced to $\operatorname{Cr}(\mathrm{V} / \mathrm{IV} / \mathrm{III})$ by different nonspecific reductants such as glutathione, glutathione reductase, cysteine, carbohydrates, NADH, $\mathrm{NADPH}$, nucleotides and ascorbic acid. The by-products of the $\mathrm{Cr}(\mathrm{VI})$ reduction process, reactive oxygen species (ROS), can attack DNA and proteins and cause them damage. Considering the composition of the bacterial cell wall (teichoic acids, polycarbohydrates and other diol-containing substances that possess reducing ability) and the activity of different specific and nonspecific membraneassociated reductases, the authors suggest that $\mathrm{Cr}(\mathrm{VI})$ can be, at least, partly reduced on the bacterial cell wall.

Equilibrium data are important for building an equation that can be used for design purposes. Gerente et al. (2007), and Pehlivan and Arslan (2007) affirm that equilibrium isotherm equations are used to describe experimental sorption data and, therefore parameters and thermodynamic assumptions of these equilibrium models usually provide some insight into the sorption mechanism, the surface properties and the affinity between sorbent and sorbate. Those authors also stated that the importance of obtaining the best fit isotherm becomes more and more significant as more applications are developed. As a consequence, more accurate and detailed isotherm descriptions are required for the design of wastewater treatment systems.

Until now, the biological reduction was tested only at laboratory scale. The applicability of a biofilm on the removal of chromium in a pilot-scale reactor was an aim of this study. On this report, the effect of the initial concentration of metal on the biosorption behavior of an Arthrobacter viscosus biofilm, in batch and column essays was also studied. Equilibrium isotherms for the adsorption of $\mathrm{Cr}(\mathrm{VI})$ on the biofilm were described by Freundlich, Langmuir, Redlich-Peterson, Dubinin-Radushkevich, Sips and Toth models and the results obtained from the batch adsorption tests were used to develop a pilot bioreactor able of remove chromium from aqueous solutions.

\section{Methods}

\subsection{Materials}

The bacterium $A$. viscosus (CECT 908) was obtained from the Spanish Type Culture Collection of the University of Valência. Aqueous chromium solutions were prepared by diluting $\mathrm{K}_{2} \mathrm{Cr}_{2} \mathrm{O}_{7}$ (Riedel) in distillated water. All glassware used for experimental purposes was washed in $60 \%$ nitric acid and subsequently rinsed with deionised water to remove any possible interference by other metals. Atomic absorption spectrometric standards were prepared from $1000 \mathrm{mg}_{\mathrm{Cr}} / \mathrm{l}$ solution.

The support was granular activated carbon (GAC) from MERCK with an average particle size of $2.5 \mathrm{~mm}$, characterized by $\mathrm{N}_{2}$ adsorption $(77 \mathrm{~K})$ with an ASAP Micromeritics 2001, which indicated a Langmuir area of $1270 \mathrm{~m}^{2} / \mathrm{g}$ and an average pore diameter of $2 \mathrm{~nm}$.

\subsection{Methods}

\subsubsection{Batch biosorption studies}

The biofilm was prepared accordingly to previous studies (Quintelas and Tavares, 2002, 2001). The batch experiments for the determination of the adsorption isotherm for chromium (VI) in solution on GAC with biofilm were performed in $250 \mathrm{ml}$ Erlenmeyer flasks containing $150 \mathrm{~mL}$ of chromium solution and $1.5 \mathrm{~g}$ of GAC covered with biofilm, at $28{ }^{\circ} \mathrm{C}$. The initial chromium concentrations varied between $50 \mathrm{mg} / \mathrm{l}$ and $1000 \mathrm{mg} / \mathrm{l}$. The flasks were rotated at a constant rate of $150 \mathrm{rpm}$ and of a temperature of $28^{\circ} \mathrm{C}$, until equilibrium was reached. Previous tests indicated that the time needed for equilibrium to be reached was five days. Samples of $5 \mathrm{~mL}$ were taken after reaching equilibrium, centrifuged at $4000 \mathrm{rpm}$ during $5 \mathrm{~min}$ and the supernatant liquid was analyzed for chromium ion.

2.2.1.1. Modelling batch biosorption. Six isotherm equations have been tested in the present study and a brief resume of the equations and parameters is presented on this section.

(A) The general Langmuir (1918) sorption model is expressed by

$Q_{\mathrm{e}}=\left(Q_{\max } b C_{\mathrm{e}}\right) /\left(1+b C_{\mathrm{e}}\right)$

$Q_{e}(\mathrm{mg} / \mathrm{g})$ is the amount of metal ion sorbed by the biofilm at equilibrium, $Q_{\max }(\mathrm{mg} / \mathrm{g})$ is the maximum metal sorption, $C_{\mathrm{e}}(\mathrm{mg} / \mathrm{l})$ is the concentration of metal in solution at the equilibrium and $b(1 /$ $\mathrm{mg}$ ) is the Langmuir adsorption equilibrium constant.

(B) Freundlich (1906) isotherm is expressed by

$Q_{\mathrm{e}}=K_{\mathrm{f}} C_{\mathrm{e}}^{1 / n}$

$Q_{\mathrm{e}}$ and $C_{\mathrm{e}}$ are the same as in the Langmuir equation, and $K_{\mathrm{f}}$ and $n$ relate to the capacity and intensity of adsorption, respectively.

(C) Reddlich and Peterson (1959) isotherm can be described as follows:

$Q_{\mathrm{e}}=\left(K_{\mathrm{R}} C_{\mathrm{e}}\right) /\left(1+a_{\mathrm{R}} C_{\mathrm{e}}^{\beta}\right)$

$K_{\mathrm{R}}(\mathrm{l} / \mathrm{g}), a_{\mathrm{R}}(1 / \mathrm{mg})$ and $\beta$ (varied between 0 and 1 ) are empirical parameters without physical meaning (Vilar et al., 2006).

(D) Sips (1948) proposed a new equation that can be expressed by

$Q_{\mathrm{e}}=\left(K_{\mathrm{S}} C_{\mathrm{e}}^{1 / b s}\right) /\left(1+a_{\mathrm{S}} C_{\mathrm{e}}^{1 / b s}\right)$

$K_{\mathrm{S}}\left(\mathrm{L}^{\mathrm{bs}} \mathrm{mg}^{1-\mathrm{bs}} / \mathrm{g}\right), a_{\mathrm{S}}(\mathrm{l} / \mathrm{mg})^{\mathrm{bs}}$ and $b_{\mathrm{S}}$ are the Sips isotherm parameters.

(E) The Toth (1971) model can be represented by the following equation:

$Q_{\mathrm{e}}=\left(K_{\mathrm{t}} C_{\mathrm{e}}\right) /\left[\left(a_{t}+C_{\mathrm{e}}\right)^{1 / t}\right]$

$K_{t}(\mathrm{mg} / \mathrm{g}), a_{t}$ and $t$ represent the Toth isotherm constants.

(F) The Dubinin and Radushkevich (1947) equation is generally expressed as follows:

$Q_{\mathrm{e}}=q_{\mathrm{D}} \exp \left(-B_{\mathrm{D}}[R T \ln (1+1 / C e)]^{2}\right)$

The constant, $B_{\mathrm{D}}$, is related to the mean free energy of sorption per gram of the sorbate as it is transferred to the surface of the solid from infinite distance in the solution. $T$ is the temperature $(K)$ and $R$ is the universal gas constant.

The simplest method to determine isotherms constants with two parameters (Langmuir, Freundlich and Dubinin-Radushkevich) is to transform those parameters so that the equation presents linear form and then linear regression is applied. For the other equations, the model parameters were estimated by non-linear regression using MATLAB and EXCEL software.

\subsubsection{Pilot bioreactor studies}

The bioreactor was a $15.8 \mathrm{~L}$ cilindric tank (inner diameter $14.2 \mathrm{~cm}$, total height $100 \mathrm{~cm}$ ), with a maximum packing fraccion of $1 / 3$. The biofilm formation was prepared accordingly to Section 2.2.1, adjusted to the bioreactor dimensions. About $2 \mathrm{~kg}$ of GAC were placed in a 51 Erlenmeyer flask with distilled water. It was heated at $120^{\circ} \mathrm{C}$ for $20 \mathrm{~min}$ to release the air inside the pores. Then, it was placed in the bioreactor for open system essays. Eighteen liters of a rich nutrient broth was prepared, sterilized at $120^{\circ} \mathrm{C}$ for $30 \mathrm{~min}$, inoculed with the bacteria and were pumped through the reactor at a flow rate of $250 \mathrm{ml} / \mathrm{min}$, during $24 \mathrm{~h}$, with total recirculation. During the next $48 \mathrm{~h}, 45 \mathrm{~L}$ of a different nutrient 
broth were used to grow the biofilm also at a flow rate of $250 \mathrm{ml} /$ min, with total recirculation. The composition and purpose of the two different nutrient broths were well described in Quintelas and Tavares (2002). After biofilm formation, the bed was washed out and the metal solutions with $\mathrm{Cr}$ concentrations of 10$100 \mathrm{mg} / \mathrm{l}$ (prepared in laboratory) were passed continuously through the column with a flow rate of $25 \mathrm{ml} / \mathrm{min}$. At the end, the column was washed out and samples of the effluent were seeded in Petri plates with nutrient agar to assess the metabolic activity of the microorganism. $\mathrm{Cr}$ concentration at the inlet and at the outlet of the columns was measured by Atomic Absorption Spectroscopy, Varian Spectra AA-250 Plus, by acetylene flame emission and wavelengths of $357.9 \mathrm{~nm}, 425.4 \mathrm{~nm}$ and $520.8 \mathrm{~nm}$. The inlet solution $\mathrm{pH}$ values were also measured during the experimental essays (Jenway $350 \mathrm{pH}$ meter).

\subsubsection{Scanning electron microscopy (SEM)}

Samples of the supported biofilm were taken and analyzed (after dehydration with different concentrations of ethanol) by SEM (Leica Cambridge S360). Samples were gold coated prior to SEM observation. It was confirmed that the biofilm uniformly covered the GAC surface.

\section{Results and discussion}

The metal adsorption is strongly dependent of $\mathrm{pH}$ values. This dependence could be related to the type and ionic state of the functional groups present on the adsorbent as well as on the metal chemistry in solution (Mohanty et al., 2006). Garg et al. (2007) affirm that in the $\mathrm{pH}$ range of 1.0-6.0, chromium ions co-exist in different forms, such as $\mathrm{Cr}_{2} \mathrm{O}_{7}^{2-}, \mathrm{Cr}_{3} \mathrm{O}_{10}^{2-}, \mathrm{Cr}_{4} \mathrm{O}_{13}^{2-}$ and $\mathrm{HCrO}_{4}^{-}$, this last one being predominant. For $\mathrm{pH}$ values higher than six the predominant species are $\mathrm{CrO}_{4}^{2-}$ and $\mathrm{Cr}_{2} \mathrm{O}_{7}^{2-}$. Those authors also stressed that more adsorption at acidic $\mathrm{pH}$ indicates that an increase in $\mathrm{H}^{+}$ions on the adsorbent surface results in a significantly stronger electrostatic attraction between the positively charged adsorbent surface and the chromate ions. Reduced adsorption of $\mathrm{Cr}(\mathrm{VI})$ at $\mathrm{pH}$ values greater than 6.0 may be due the competition between the anions $\mathrm{CrO}_{4}^{2-}$ and $\mathrm{OH}^{-}$for adsorption sites on the surface of the adsorbent, with $\mathrm{OH}^{-}$predomination. It has also been postulated by Garg et al. (2007) that under acidic conditions, $\mathrm{Cr}(\mathrm{VI})$ could be reduced to $\mathrm{Cr}(\mathrm{III})$ in the presence of an adsorbent. On the other hand, studies developed by Leyva Ramos et al. (1994) show that the maximum adsorption occurred at $\mathrm{pH} 6$ and the adsorption capacity was reduced about 17 times when $\mathrm{pH}$ was increased from 6 to 10. More recently, Krishnani et al. (2008) affirm that the reduction of $\mathrm{Cr}(\mathrm{VI})$ mainly depends on the proton concentration in solution, as the higher the proton concentration, the higher the efficiency of $\mathrm{Cr}(\mathrm{VI})$ reduction. This can be explained by a surface exchange reaction between chromate and hydroxyl ions, which favors chromate adsorption in acidic media and by the reduction process of hexavalent to trivalent chromium, which requires a large amount of protons. These statements reinforce the decision of using chromium solutions with $\mathrm{pH}$ values in the range 5-5.5 in all the experimental essays of this study.

\subsection{Effect of the initial chromium concentration}

It was observed that as the initial chromium concentration increases, the uptake increases too, but the removal percentage decreases. On changing the initial chromium concentration from 5\% to $1000 \mathrm{mg} / \mathrm{l}$, the amount of chromium biosorbed increased from $0.48 \%$ to $38.28 \mathrm{mg} / \mathrm{g}$, but the removal percentage decreased from $95.20 \%$ to $38.28 \%$ (Table 1 ). At lower concentrations, the ratio between the initial number of moles of chromium in solution and
Table 1

Equilibrium concentrations and removal percentages of $\operatorname{Cr}(\mathrm{VI})$ ion obtained at different initial metal ion concentration $\left(28^{\circ} \mathrm{C}, 150 \mathrm{rpm}\right)$

\begin{tabular}{lcc}
\hline $\mathrm{C}_{0}(\mathrm{mg} / \mathrm{l})$ & $\mathrm{C}_{\mathrm{eq}}(\mathrm{mg} / \mathrm{l})$ & $\mathrm{Rp}(\%)$ \\
\hline Arthrobacter viscosus & & \\
5 & 0.24 & 95.2 \\
10 & 0.26 & 97.4 \\
25 & 1.26 & 95.0 \\
50 & 6.10 & 87.8 \\
250 & 90.67 & 63.7 \\
500 & 263.35 & 47.3 \\
750 & 403.26 & 46.2 \\
1000 & 617.23 & 38.3 \\
\hline
\end{tabular}

the available surface area is low and subsequently the sorption is independent of the initial concentrations. On the other hand, at higher concentrations the available sites become fewer compared to the number of moles of chromium present and hence the removal percentage of chromium is dependent on the initial percentage (Padmesh et al., 2006). Horsfall et al. (2006) reinforce this idea and affirm that this decrease on the removal percentage when the initial concentration increased is due to the increase of the number of ions competing for the available binding sites on the biomass and to the lack of binding sites at higher concentration levels. At higher concentrations, the reduced average distance between the adsorbing species affects the charge distribution of their neighbours, thus altering the ability of the species to migrate to the biomass surface and resulting in reduced fixation.

Akhtar et al. (2007) explain that at higher equilibrium concentrations, uptake by surface binding was negligible due to saturation of biosorbent binding sites. The increase in biosorption capacity at higher concentrations could be related to the different concentration gradient between the solution and the inside of the microbial cells and due to penetration of metal ions inside the cells rather than surface adsorption. At very high solute level, solid-liquid equilibrium becomes limited by diffusion of metal ions into the cells.

\subsection{Adsorption isotherms}

The fixation capacity of an adsorbent towards a specific adsorbate can be described by different equilibrium sorption isotherm models, which are characterized by constants that express the surface properties and affinity between the adsorbent and the adsorbate.

Adsorption first presents a linear rising with instantaneous and extremely fast uptake, followed by a stationary state. Pehlivan and Arslan (2007) and Ertugay and Bayhan (2007) explain that the first step could be attributed to the instantaneous utilization of the most available adsorbing sites on the adsorbent surface and the second part of the isotherm curve may be attributed to a very slow diffusion of the metal through the sorbent micropores. Akhtar et al. (2007), affirm that the fast biosorption kinetics observed initially is typical of biosorption process involving no energy-mediated reactions and metal removal from solution is due to purely physicochemical interactions between biomass and metal solution.

For the biosorbent used (Biofilm $+\mathrm{GAC}$ ), equilibrium data were experimentally determined. The $Q_{e}$ represents the practical limiting adsorption capacity and allows the comparison of adsorption performance, particulary in the cases where the sorbent does not reach its full saturation in experiments (Aksu, 2001) and $C_{\mathrm{e}}$ represents de equilibrium concentration in solution. Six different models (Langmuir, Freundlich, Redlich-Peterson, DubininRadushkevich, Sips and Toth) were fitted to experimental data and the calculated constants are presented in Table 2 . This table also shows the $R$ parameter of each adjustment. All equations fit the data reasonably well (Fig. 1) but the best fit was obtained with the Freundlich isotherm model. The fact that the fit obtained with 
Langmuir model showed the worst results, suggests that the binding of chromium does not occur as a monolayer on the surface of the biomass. Vázquez et al. (2006) suggested that the disagreement with the Langmuir model might be due to the heterogeneity of the biosorbent surface with resulting variation in adsorption energy. Aksu and Balibek (2007) affirm that values for $1 / b_{S}>1$ (from the Sips model) indicates heterogeneous adsorbents. The fact that a value of 2.1 was obtained for the $1 / b_{\mathrm{S}}$ and the disagreement with the Langmuir model suggests heterogeneity of the biosorbent used.

Another interpretation of surface binding site heterogeneity has been proposed by Scatchard (1949) and Dahlquist (1978). Accordingly to Krishnani et al. (2008), if a straight line is obtained by plotting $Q_{\mathrm{e}} / C_{\mathrm{e}}$ versus $Q_{\mathrm{e}}$ then the sorbent presents only one type of sites, a convex curvature indicates a single site binding with positive cooperative between each other and a concave curve shows the binding with a negative cooperative phenomenon between strong and weak binding sites. In this study, the Scatchard and Dahlquist plot presents concave curve which indicates the presence of two different types of site.

The value obtained for the maximum adsorption capacity with the biofilm of $A$. viscosus supported on GAC $(38.3 \mathrm{mg} / \mathrm{g})$ is higher than those obtained for the removal of $\mathrm{Cr}(\mathrm{VI})$ with Saccharomyces cerevisiae (6.8 mg/g) (Goyal et al., 2003), Candida utilis $(7.0 \mathrm{mg} / \mathrm{g}$ ) (Muter et al., 2002), Neurospora crassa (15.9 mg/g), Chlamydomonas reinhardtii (18.2 mg/g) (Arica et al., 2005) and Bacillus thuringiensis (28.6 mg/g) (Sahin and Ozturk, 2005).

\subsection{Pilot bioreactor studies}

The biological reduction of $\mathrm{Cr}(\mathrm{VI})$ has been well studied along the last two decades, in laboratory studies. The extensive use of chromium in industry is responsible for the discharge of large amounts of chromium being discharged into the environment. A pilot scale reactor test is a very important step for the industrial implementation of a biosorption system. No special measures were taken to avoid contamination as, at industrial scale, those measures would become very expensive; the study of a biosorption system consisting in a biofilm of $A$. viscosus supported on GAC capable of treating large amounts of chromium contaminated solutions, for industrial usage, is the aim of this work.

The bacteria A. viscosus is a good exopolysaccharide producer (EPS), which allows good qualities for adhesion to the support, for metal ions entrapment and contribute to the formation of a protective barrier against harmful effects. These capabilities rein-

Table 2

Adsorption constants and adjustment regression parameter for the isotherm models studied for chromium (VI) onto a biofilm of $A$. viscosus supported on GAC

\begin{tabular}{llll}
\hline Langmuir parameters & & & \\
$Q_{\max }$ & $b$ & & $R^{2}$ \\
29.240 & 0.0288 & & 0.985 \\
Freundlich parameters & & & \\
$K_{\mathrm{f}}$ & $n$ & & $R^{2}$ \\
1.935 & 2.144 & & 0.998 \\
Dubinin-Radushkevich parameters & $B_{\mathrm{D}}$ & & \\
$q_{\mathrm{D}}$ & 9.811 & & $R^{2}$ \\
33.385 & $a_{\mathrm{R}}$ & $\beta$ & 0.804 \\
Redlich-Peterson parameters & 0.522 & \\
$K_{\mathrm{R}}$ & 33.680 & & $R^{2}$ \\
61.220 & & $b_{\mathrm{S}}$ & 0.992 \\
Sips parameters & $a_{\mathrm{S}}$ & 0.478 & $R^{2}$ \\
$K_{\mathrm{S}}$ & -0.0004 & & 0.992 \\
1.806 & & $t$ & \\
Toth parameters & $a_{\mathrm{t}}$ & 1.916 & $R^{2}$ \\
$K_{\mathrm{t}}$ & 0.0555 & & 0.992 \\
1.811 & & & \\
\hline
\end{tabular}

force the decision to use these bacteria for the pilot scale reactor studies. The use of a support provides the necessary surface for the development of biofilm structures. Biofilms provide high biomass concentration per unit volume, while bacteria can remain in the reactor for unlimited time, thus allowing the bacteria to adjust to the environmental conditions (Dermou et al., 2005).

The biofilm of $A$. viscosus supported on GAC was tested for the initial $\mathrm{Cr}(\mathrm{VI})$ concentrations of $10-100 \mathrm{mg} / \mathrm{l}$. The essay for the initial concentration of $10 \mathrm{mg} / \mathrm{l}$ was followed during 226 days (approximately 7.5 months) and the essay for the initial concentration of $100 \mathrm{mg} / \mathrm{l}$ lasted during 104 days (approximately 3.5 months). The volume of chromium solution treated was of $8140 \mathrm{l}$ for the essay with the initial concentration of $10 \mathrm{mg} / \mathrm{l}$ and of $3732 \mathrm{~L}$ for the more concentrated solution. The results in terms of breakthrough curves, for both initial concentrations, are presented in Fig. 2.

It is important to refer that at the end of each run, columns were washed out and samples of the effluent were seeded in Petri plates with nutrient agar to assess the metabolic activity of the microorganism and even concentrations of $100 \mathrm{mg} / \mathrm{l}$ did not seem to be toxic for the bacterial culture used, indicating that this specific culture appears to be resistant in an actual industrial environment. After the biofilm formation, the microorganism survived without any kind of nutrients. It is possible to conclude that the bacteria incorporate chromium on their metabolism and this is probably the reason why the bacteria were metabolically active after several months without nutritional supplements. This conclusion is extremely important because the addiction of a pollutant to the nutrient supply of a microorganism is a fundamental step for the success of a biosorption process.

The removal percentage for the experimental essay at initial concentration of $10 \mathrm{mg} / \mathrm{l}$ was of $100 \%$ during the first 26 days of the experimental run. At the 27th day, the removal percentage started to decrease and after 226 days, the removal percentage was $32 \%$. For the experimental essay with initial concentration of $100 \mathrm{mg} / \mathrm{l}$, the removal percentage was $100 \%$ during the first six days of the experimental run. At the end of the experiment, the removal percentage was $38 \%$. Comparing the removal percentages obtained for the two different initial concentrations, it becomes apparent that with the increase in chromium concentration the bioremoval efficiency decreases. This evidence could plausibly be attributed to the inhibitory effect of chromium on the microorganism at higher concentrations (Radhika et al., 2006).

At the end of the experiments, the biofilm was analyzed by SEM (scanning electron microscopy) and it is possible to confirm the presence of a large number of bacteria. Some degradation of the activated carbon was detected. This state of degradation is a consequence of erosion motivated by the hydrodynamic effects suffered by carbon during the 226 days of experimental essay. The biofilm from the bioreactor operating with the initial concentration of $100 \mathrm{mg} / \mathrm{l}$, covered uniformly the carbon surface. The activated carbon remains less degradated than the carbon used for the experimental essay at an initial concentration of $10 \mathrm{mg} / \mathrm{l}$ and this is justified by the lower erosion suffered due to a shorter essay period.

Studies developed by Battaglia-Brunet et al. (2006) showed a removal percentage of $\mathrm{Cr}(\mathrm{VI})$ of $100 \%$ during the first 18 days of experimental essay. These studies were developed in a pilot bioreactor, inoculated with a bacterial population containing the sulphate- reducing organism Desulfomicrobium norvegicum, for the treatment of a $\mathrm{Cr}(\mathrm{VI})$ solution with an initial concentration of $15 \mathrm{mg} / \mathrm{l}$

Barros et al. (2007) inoculated a reactor with wastewater sludge for the treatment of a chromium solution with an initial concentration of $10 \mathrm{mg} / \mathrm{l}$. This reactor was operating during 30 days and the authors verified that the average removal percentage of $90.4 \%$ 

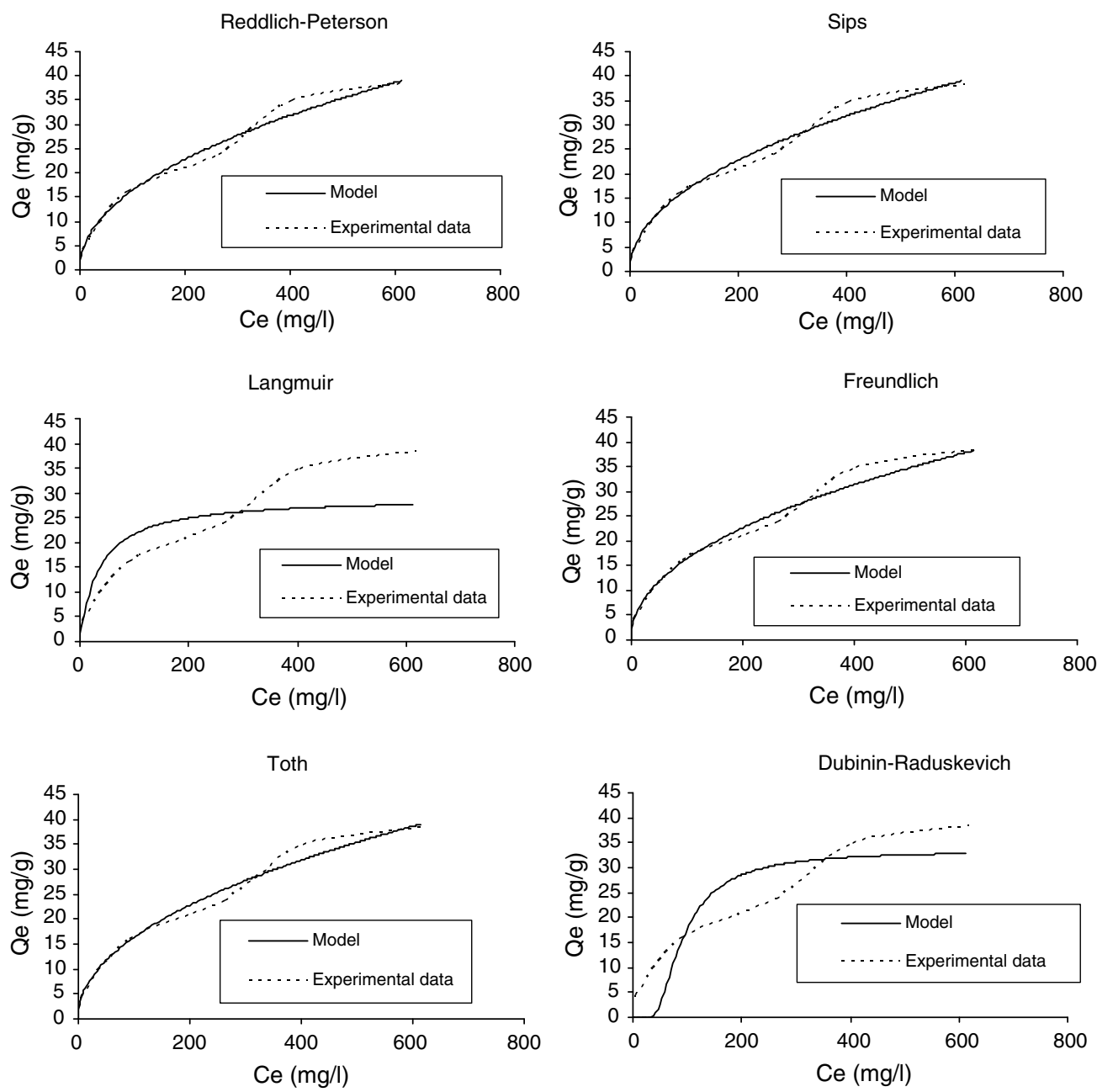

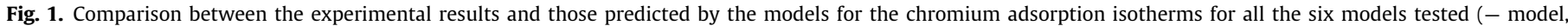
------ experimental data).

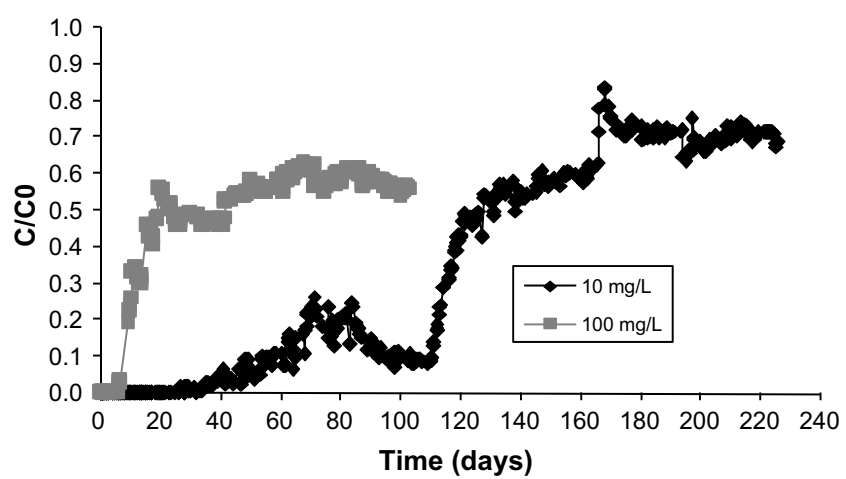

Fig. 2. Breakthrough curves for the biosorption of $\mathrm{Cr}(\mathrm{VI})$ using an $A$. viscosus biofilm supported on GAC, for the initial $\mathrm{Cr}(\mathrm{VI})$ concentrations of 10 and $100 \mathrm{mg} / \mathrm{l}$.

varying from $96.1 \%$ to $60.8 \%$. In the pilot bioreactor presented herein and considering the results obtained during the first 30 days, for the initial concentration of $10 \mathrm{mg} / \mathrm{l}$, an average removal percentage of $99.9 \%$ was obtained, varying from $100 \%$ to $99.3 \%$.

The uptake values obtained for the pilot-scale bioreactor were $11.35 \mathrm{mg} / \mathrm{g}$ and $14.55 \mathrm{mg} / \mathrm{g}$, respectively for the initial chromium concentrations of 10 and $100 \mathrm{mg} / \mathrm{l}$. These values were compared with previous results obtained using minicolumns (Quintelas et al., 2006), $0.72 \mathrm{mg} / \mathrm{g}$ and $5.30 \mathrm{mg} / \mathrm{g}$, for the initial chromium concentrations of $10 \mathrm{mg} / \mathrm{l}$ and $100 \mathrm{mg} / \mathrm{l}$, respectively. It is evident that the uptake values obtained with the pilot bioreactor are much higher than those obtained with the minicolumns. The higher amount of carbon and consequent amount of biomass and the increase of the retention time are possible reasons for the increase on the uptake values.

These results are very promising. The high removal rates of hexavalent chromium that were achieved indicate a feasible, economical and efficient process for biological hexavalent chromium removal from industrial wastewater effluents.

\section{Conclusions}

The behavior of a biosorption system consisting of an A. viscosus biofilm supported on GAC was investigated in a batch system. Six different adsorption models for equilibrium were applied to describe the experimental isotherms and isotherm constants were determined. Data were very well fitted by the Freundlich model. It was observed that as initial chromium concentration increases, the uptake increases too, but the removal percentage decreases. When the initial chromium concentration increases from $5 \mathrm{mg} / \mathrm{l}$ to $1000 \mathrm{mg} / \mathrm{l}$, the amount of chromium biosorbed increased from $0.48 \mathrm{mg} / \mathrm{g}$ to $38.28 \mathrm{mg} / \mathrm{g}$, but the removal percentage decreased 
from $95.20 \%$ to $38.28 \%$. Studies made with a pilot scale bioreactor showed average removal percentage of $99.9 \%$, during the first 30 days, for the initial concentration of $10 \mathrm{mg} / \mathrm{l}$ and average removal percentage of $72 \%$, for the same period and for the initial concentration of $100 \mathrm{mg} / \mathrm{l}$. Uptakes values of $11.35 \mathrm{mg} / \mathrm{l}$ and $14.55 \mathrm{mg} / \mathrm{l}$ were obtained, respectively, for the initial concentration of $10 \mathrm{mg} / \mathrm{l}$ and $100 \mathrm{mg} / \mathrm{l}$. These values are much higher than the obtained in previous studies developed with minicolumns. After the biofilm formation, the microorganism survived without any kind of nutrients allowing to conclude that the bacteria incorporate chromium on their metabolism and this is probably the reason why the bacteria were metabolically active after several months without nutritional supplements.

\section{Acknowledgements}

The authors would like to gratefully acknowledge the financial support of this project by the Fundação para a Ciência e Tecnologia, Ministério da Ciência e Tecnologia, Portugal (POCTI/CTA/44449/ 2002) and (SFRH/BD/8646/2002), financed by FEDER.

\section{References}

Akar, T., Tunali, S., 2006. Biosorption characteristics of Aspergillus flavus biomass for removal of $\mathrm{Pb}(\mathrm{II})$ and $\mathrm{Cu}(\mathrm{II})$ ions from an aqueous solution. Bioresour. Technol. $97,1780-1787$

Akhtar, K., Akhtar, M.W., Khalid, A.M., 2007. Removal and recovery of uranium from aqueous solutions by Trichoderma harzianum. Water Res. 41, 13661378.

Aksu, Z., 2001. Equilibrium and kinetic modelling of cadmium (II) biosorption by $C$. vulgaris: in a batch system: effect of temperature. Sep. Purif. Technol. 21, 285294.

Aksu, Z., Balibek, E., 2007. Chromium(VI) biosorption by dried Rhizopus arrhizus: effect of salt $(\mathrm{NaCl})$ concentration on equilibrium and kinetic parameters. J. Hazard. Mater. 145, 210-220.

Aksu, Z., Donmez, G., 2006. Binary biosorption of cadmium (II) and nickel (II) onto dried Chlorella vulgaris: co-ion effect on mono-component isotherm parameters. Process Biochem. 41, 860-868.

Ahluwalia, S.S., Goyal, D., 2007. Microbial and plant derived biomass for removal of heavy metals from wastewater. Bioresour. Technol. 98, 2243-2257.

Arica, M.Y., Tuzun, I., Yalçin, E., Ince, O., Bayramoglu, G., 2005. Utilisation of native, heat and acid-treated microalgae Chlamydomonas reinhardtii preparation for biosorption of $\mathrm{Cr}(\mathrm{VI})$ ions. Process Biochem. 40, 2351-2358.

Arica, M.Y. Bayramoglu, G. Yilmaz, M. Ince, O., Bektas, S., Genc, O, 2004. Biosorption of $\mathrm{Hg}^{2+}, \mathrm{Cd}^{2+}$, and $\mathrm{Zn}^{2+}$ by Ca-alginate and immobilized fungus Funalia trogii. J. Hazard. Mater. B 109, 191-199.

Asatiani, N.V., Abuladze, M.K. Kartvelishvili, T.M., Bakradze, N.G Sapojnikova, N.A Tsibakhashvili, N.Y., Tabatadze, L.V., Lejava, L.V., Asanishvili, L.L., Holman, $\mathrm{H}_{-}$ Y.H.-Y., 2004. Effect of chromium(VI) action on Arthrobacter oxydans. Curr Microbiol. 49, 321-326.

Barros, A.J.M., Prasad, S., Leite, V.D., Souza, A.G., 2007. Biosorption of heavy metals in upflow sludge columns. Bioresour. Technol. 98, 1418-1425.

Battaglia-Brunet, F., Touzé, S., Michel, C., Ignatiadis, I., 2006. Treatment of chromatepolluted groundwater in a $200 \mathrm{dm}^{3}$ pilot bioreactor fed with hydrogen. J. Chem. Technol. Biotechnol. 81, 1506-1513.

Bayramoglu, G., Çelik, G., Arica, M.Y., 2006. Studies on accumulation of uranium by fungus Lentinus sajor-caju. J. Hazard. Mater. B 136, 345-353.

Cossich, E.S., da Silva, E.D., Tavares, C.R.G., Filho, L.C., Ravagnani, T.M.K., 2004 Biosorption of chromium (III) by biomass of seaweed Sargassum sp. in a fixedbed column. Adsorption 10, 129-138.

Dahlquist, F.W. 1978. The meaning of Scatchard and Hill plots. In: Hirs, C.H.W. Timasheff, S.N. (Eds.), Methods of Enzymology. Academic Press, New York, pp. 270-299.

Deng, L., Su, Y., Su, H., Wang, X., Zhu, X., 2006. Biosorption of copper (II) and lead (II) from aqueous solutions by nonliving green algae Cladophora fasciculares: equilibrium, kinetics and environmental effects. Adsorption 12, 267-277.

Dermou, E., Velissariou, A., Xenos, D., Vayenas, D.V., 2005. Biological chromium (VI) reduction using a trickling filter. J. Hazard. Mater. B 126, 78-85.

Dubinin, M.M., Radushkevich, L.V., 1947. The equation of the characteristic curve of activated charcoal. Dokl. Akad. Nauk SSSR 55, 327-329.

Ertugay, N., Bayhan, Y.K., 2007. Biosorption of $\mathrm{Cr}(\mathrm{VI})$ from aqueous solutions by biomass of Agaricus bisporus. J. Hazard. Mater. 154, 432-439.

Freundlich, H., 1906. Adsorption in solutions. Phys. Chem. 57, 384-410.

Garg, U.K., Kaur, M.P., Garg, V.K., Sud, D., 2007. Removal of hexavalent chromium from aqueous solution by agricultural waste biomass. J. Hazard. Mater. 140, 60-

Gerente, C., Lee, V.K.C., Le Cloirec, P., McKay, G., 2007. Application of chitosan for the removal of metals from wastewaters by adsorption-mechanisms and models review. Rev. Environ. Sci. Biotechnol. 37, 41-127.
Goyal, N., Jain, S.C., Banerjee, U.C., 2003. Comparative studies on the microbial adsorption of heavy metals. Adv. Environ. Res. 7, 311-319.

Han, R., Li, H., Li, Y., Zhang, J., Xiao, H., Shi, J., 2006. Biosorption of copper and lead ions by waste beer yeast. J. Hazard. Mater. 137, 1569-1576.

Hashim, M.A., Chu, K.H., 2004. Biosorption of cadmium by brown, green and red seaweeds. Chem. Eng. J. 97, 249-255.

Horsfall Jr., M., Ogban, F., Akporhonor, E.E., 2006. Sorption of chromium (VI) from aqueous solution by cassava (Manihot sculenta CRANZ) waste biomass. Chem. Biodivers. 3, 161-173.

Kazy, S., Das, S.K., Sar, P., 2006. Lanthanum biosorption by a Pseudomonas sp.: equilibrium studies and chemical characterization. J. Ind. Microbiol. Biotechnol. 33, 773-783.

Kiran, B., Kaushik, A., Kaushik, C.P., 2007. Biosorption of $\mathrm{Cr}(\mathrm{VI})$ by native isolate of Lyngbya putealis (HH-15) in the presence of salts. J. Hazard. Mater. 141, 662667.

Kobya, M., Dermirbas, E., Senturk, E., Ince, M., 2005. Adsorption of heavy metals ions from aqueous solutions by activated carbon prepared from apricot stone. Bioresour. Technol. 96, 1518-1521.

Krishnani, K.K., Mengb, X., Christodoulatos, C., Bodduc, V.M., 2008. Biosorption mechanism of nine different heavy metals onto biomatrix from rice husk. J. Hazard. Mater. 153, 1222-1234.

Lameiras, S., Quintelas, C., Tavares, M.T., 2008. Development of a biosorption system for chromium (VI) using a Arthrobacter viscosus biofilm supported on granular activated carbon and on natural zeolites. Bioresour. Technol. 99, 206-801.

Langmuir, I., 1918. Adsorption of gases on plane surfaces of glass, mica and platinum. J. Am. Chem. Soc. 40, 1361-1403.

Leyva Ramos, R., Juarez Martinez, A., Guerrero Coronado, R.M., 1994. Adsorption of chromium (VI) from aqueous solutions on activated carbon. Water Sci. Techol. 30, 191-197.

Mohanty, K., Jha, M., Meikap, B.C., Biswas, M.N., 2006. Biosorption of $\operatorname{Cr}(\mathrm{VI})$ from aqueous solutions by Eichhornia crassipes. Chem. Eng. J. 117, 71-77.

Muter, O., Lubinya, I., Millers, D., Grigorjeva, L., Ventinya, E., Rapoport, A., 2002. $\mathrm{Cr}(\mathrm{VI})$ sorption by intact and dehydrated Candida utilis cells in the presence of other metals. Process Biochem. 38, 123-131.

Özer, A., Özer, D., Ekíz, H.Í., 2004. The equilibrium and kinetic modelling of the biosorption of copper (II) ions on Cladophora crispate. Adsorption 10, 317326.

Padmesh, T.V.N., Vijayaraghavan, K., Sekaran, G., Velan, M., 2006. Biosorption of acid blue 15 using fresh water macroalga Azolla filiculoides: batch and column studies. Dyes Pigments 71, 77-82.

Pehlivan, E., Arslan, G., 2007. Removal of metal ions using lignite in aqueous solution - low cost biosorbents. Fuel Process. Technol. 88, 99-106.

Quintelas, C., Tavares, T., 2001. Removal of chromium (VI) and cadmium (II) from aqueous solution by a bacterial biofilm supported on granular activated carbon. Biotechnol. Lett. 23, 1349-1353.

Quintelas, C., Tavares, T., 2002. Lead (II) and iron (II) removal from aqueous solution: Biosorption by a bacterial biofilm supported on granular activated carbon. J. Res. Environ. Biotechnol. 3, 196-202.

Quintelas, C., Sousa, E., Silva, F., Neto, S., Tavares, T., 2006. Competitive biosorption of ortho-cresol, phenol, chlorophenol and chromium (VI) from aqueous solution by a bacterial biofilm supported on granular activated carbon. Process Biochem. 41, 2087-2091.

Quintelas, C., Fernandes, B., Castro, J., Figueiredo, H., Tavares, T., 2008a. Biosorption of $\mathrm{Cr}(\mathrm{VI})$ by a Bacillus coagulans biofilm supported on granular activated carbon (GAC). Chem. Eng. J. 136, 195-203.

Quintelas, C., Fernandes, B., Castro, J., Figueiredo, H., Tavares, T., 2008b. Biosorption of $\mathrm{Cr}(\mathrm{VI})$ by three different bacterial species supported on granular activated carbon - a comparative study. J. Hazard. Mater. 153, 799-809.

Radhika, V., Subramanian, S., Natarajan, K.A., 2006. Bioremediation of zinc using Desulfotomaculum nigrificans: Bioprecipitation and characterization studies. Water Res. 40, 3628-3636.

Reddlich, O., Peterson, D.L., 1959. A useful adsorption isotherm. J. Phys. Chem. 63, 1024

Sahin, Y., Ozturk, A., 2005. Biosorption of chromium (VI) ions from aqueous solution by bacterium Bacillus thuringiensis. Process Biochem. 40, 1895-1901.

Satapathy, D., Natarajan, G.S., Patil, S.J., 2005. Adsorption characteristics of chromium (VI) on granular activated carbon. J. Chin. Chem. Soc. 52, 35-44.

Scatchard, G., 1949. The attraction of proteins for small molecules and ions. Ann. NY Acad. Sci. 51, 600-672.

Sips, R., 1948. Combined form of Langmuir and Freundlich equations. J. Chem. Phys. $16,490-495$.

Solóniz, M.I., Balsalobre, L., Alba, C., Valderrama, MJ.M.J., Peinado, J.M., 2002. Feasibility of cooper uptake by the yeast Pichia guilliermondii isolated from sewage sludge. Res. Microbiol. 153, 173-180.

Song, Z., Edwards, S.R., Burns, R.G., 2006. Treatment of naphthalene-2-sulfonic acid from tannery wastewater by a granular activated carbon fixed bed inoculated with bacterial isolates Arthrobacter globiformis and Comamonas testosterone. Water Res. 40, 495-506.

Toth, J., 1971. State equations of the solid-gas interface layer. Acta Chim. Acad. Sci. Hung. 69, 311-328.

Tunali, S., Çabuk, A., Akar, T., 2006. Removal of lead and copper ions from aqueous solutions by bacterial strain isolated from soil. Chem. Eng. J. 115, 203-211.

Tunali, S., Kiran, I., Akar, T., 2005. Chromium (VI) biosorption characteristics of Neurospora crassa fungal biomass. Miner. Eng. 18, 681-689.

Urrutia, M.M., 1997. General Bacterial Sorption Processes. Taylor and Francis Publishers, London. pp. 39-66. 
226

C. Quintelas et al./Bioresource Technology 100 (2009) 220-226

Vázquez, G., González-Álvarez, J., Garcia, A.I., Freire, M.S., Antorrena, G., 2006. Adsorption of phenol on formaldehyde-pretreated Pinus pinaster bark: Equilibrium and kinetics. Bioresour. Technol. 98, 1535-1540.
Vilar, V.J.P., Botelho, C.M.S., Boaventura, R.A.R., 2006. Equilibrium and kinetic modelling of Cd (II) biosorption by algae Gelidium and agar extraction algal waste. Water Res. 40, 291-302. 